\title{
Changes in dinoflagellate intracellular amino acids in response to diurnal changes in light and N supply
}

\author{
Krystyna Flynn ${ }^{1}$, Kevin J. Flynn ${ }^{1, *}$, Kenneth J. Jones ${ }^{2}$ \\ 'Algal Research Unit, School of Biological Sciences, University of Wales Swansea, Singleton Park, Swansea SA2 8PP, Wales, UK \\ ${ }^{2}$ Dunstaffnage Marine Laboratory, PO Box 3, Oban, Argyll PA34 4AD, Scotland, UK
}

\begin{abstract}
Seven species of dinoflagellates were examined with respect to their intracellular amino acid (InAA) content under different conditions of $\mathrm{N}$-nutrition and light, and for release of dissolved free amino acids (DFAA). Alexandrium spp. did not contain significant amounts of a neutral nonprotein amine present in all other phototrophic dinoflagellates tested but, in contrast, it always maintained high levels of glutamine and of the ratio of intracellular glutamine/glutamate (Gln/Glu). Dinoflagellates responded to a decreased availability of $\mathrm{N}$ with a fall in Gln/Glu but, unlike other microalgae, arginine was always a significant component of InAA. Refeeding of $\mathrm{N}$-limited cultures with nitrate during the dark phase of growth, simulating refeeding of a natural population following a diurnal migration to the nutricline, resulted in an increased Gln/Glu during the dark phase followed by a decline during the light phase. $\mathrm{N}$-refeeding of $\mathrm{N}$-deprived cells led a rapid rise in the ratio, except during $\mathrm{N}$-refeeding of stationary phase Gymnodinium catenatum (which were of abnormal shape and motility) when Glu rather than Gln increased. The sensitivity of the analytical method would enable sampling from natural dinoflagellate populations in order to assess their physiological status; extracts from 200 to 2000 cells, depending on cell size, are sufficient. A significant quantity of an unidentified amino acid accumulated in the growth media of Gymnodinium catenatum but otherwise DFAA in dinoflagellate culture media were similar to that from other microalgae.
\end{abstract}

\section{INTRODUCTION}

The occurrence of dinoflagellate blooms may be due to in situ growth or to advective processes causing the aggregation of algae from over a wide area (Holligan et al. 1984, Le Févre 1986, Franks \& Anderson 1992). In addition, paralytic shellfish poisoning (PSP) toxicity associated with some dinoflagellate populations is suspected to be related, in some way, to the nutritional status of those algae (e.g. Trick et al. 1981, Anderson et al. 1990). Fundamental to an understanding of the ecology of dinoflagellates during such events is a consideration of the physiological status of these populations. Flynn (1990a) suggests that the ratio of intracellular free glutamine to glutamate (Gln/Glu) may be useful in following the $\mathrm{N}$-status of algae in natural

\footnotetext{
-Addressee for correspondence
}

waters, such as during the diurnal vertical migration of some dinoflagellate populations (Cullen \& Horrigan 1981, Figueiras \& Fraga 1990) and during bloom formation (Figueiras \& Pazos 1991). In addition, because arginine and ornithine are precursors for PSP toxins (Shimizu et al. 1990), information on the qualitative composition of the intracellular amino acid pool (InAA) is also likely to be of use (e.g. Anderson et al. 1990).

However, there are 2 potential problems. Firstly, some flagellates such as Isochrysis galbana and Dunaliella primolecta (Flynn 1990a) exhibit cyclic diurnal variations in Gln/Glu with Gln/Glu not only going low during $\mathrm{N}$-deprivation but also during the dark phase of $\mathrm{N}$-sufficient growth. Secondly, we have noted recently (Flynn \& Flynn 1992) that there are various nonprotein amino acids which can interfere with the analysis of free protein intracellular amino acids.

The aims of this work were to consider the effects of growth in light/dark (L/D) cycles and changes in the 
$\mathrm{N}$-status of dinoflagellates on the content of InAA in order to test the usefulness of the approach and whether the analytical procedure is sensitive enough for use with natural populations.

\section{MATERIALS AND METHODS}

The species tested, with strain types and typical cell volumes, were Aureodinium pigmentosum (PCC 208; $200 \mathrm{fl}$ ), Prorocentrum micans (CCAP 1136/8; $10000 \mathrm{fl}$ ), Glenodinium foliaceum (CCAP 1116/3; $10000 \mathrm{fl}$ ), Heterocapsa triquetra (PCC 169; 2100 fl), Scrippsiella trochoidea (CCAP 1134/5; $3200 \mathrm{fl}$ ). Alexandrium tamarense (PCC 173 supplied by CCAP; $8000 \mathrm{fl}$ ) and Gymnodinium catenatum (Institute Español de Oceanografia Vigo, Spain; 28000 fl) (PCC: Plymouth Culture Collection, Plymouth Marine Laboratory, Plymouth, UK; CCAP: Culture Collection of Algae \& Protozoa, Dunstaffnage Marine Laboratory, Oban, UK). Of these, only Gymnodinium catenatum is known to be toxic. Sterile precautions were taken although none of the cultures were axenic.

All cultures were grown in enriched natural seawater medium (f/2; Guillard \& Ryther 1962) usually with less than $100 \mu \mathrm{M}$ nitrate and $18 \mu \mathrm{M}$ phosphate, in a $12 \mathrm{~h} / 12 \mathrm{~h}$ L/D cycle (PAR photon flux density of $150 \mu \mathrm{mol} \mathrm{m} \mathrm{m}^{-2} \mathrm{~s}^{-1}$ from warm white fluorescent tubes) at $15^{\circ} \mathrm{C}$. Experimental flasks were static (aeration or stirring caused death or damage) and supplied with light at $180 \mu \mathrm{mol} \mathrm{m} \mathrm{m}^{-2} \mathrm{~s}^{-1}$; samples were withdrawn through a glass syphon tube. Media for experimental flasks were filter sterilized by passage through a $0.2 \mu \mathrm{m}$ pore Durapore (Millipore) filter. If applicable, additional medium was pumped into the vessels (2 I conical flasks) using a peristaltic pump with 'Marprene' tubing (Watson-Marlow, Falmouth, UK). Cell counts were by microscopy using a SedgewickRafter chamber; motility and general appearance were noted before fixing the cells with Lugol's iodine. Cell division occurred during late dark phase. Cell sizes were estimated using an Elzone 282PC (Particle Data Europe) particle analyzer with a $76 \mu \mathrm{m}$ orifice.

Samples $(5$ to $20 \mathrm{ml}$ ) for extraction of intracellular amino acids (InAA) were collected under low $(50 \mathrm{~mm}$ $\mathrm{Hg}$ ) or no vacuum, onto pre-ashed glassfibre filters (Gelman type AE, $13 \mathrm{~mm}$ diameter). The first few $\mathrm{ml}$ of eluent was collected for analysis of dissolved free amino acids (DFAA). The filters were kept frozen $\left(-20^{\circ} \mathrm{C}\right)$ in $1.5 \mathrm{ml}$ microtubes prior to extraction with HPLC grade water at $70^{\circ} \mathrm{C}$. InAA and DFAA were analysed either by the method of Flynn (1988) or that of Flynn \& Flynn (1992). Amino acid concentrations are given as $\mathrm{mM}$, using average cell volumes for each species. (Note however that, as the compartmentalization of the amines is not known, these concentrations have little biochemical meaning.)

Four types of study were undertaken. (1) The diurnal cycle of InAA was studied in all cultures in exponential growth phase with excess nitrate (initial of $500 \mu \mathrm{M}$ nitrate). (2) The effects of nitrate-limited growth $(50 \mu \mathrm{M}$ nitrate and $10 \mu \mathrm{M}$ phosphate) with nitrate feeding during either the complete L/D cycle or during the dark phase alone was studied for Prorocentrum micans and Scrippsiella trochoidea using cultures grown at a dilution rate equivalent to $0.3 \mathrm{~d}^{-1}$. (3) The response to ammonium-spiking (10 $\mu \mathrm{M}$ ammonium) for all cultures was studied in the light phase, with cultures previously grown on $50 \mu \mathrm{M}$ nitrate through into stationary phase. (4) The InAA of Alexandrium tamarense and Gymnodinium catenatum were studied during $\mathrm{N}$-limited growth $(20 \mu \mathrm{M}$ nitrate and $5 \mu \mathrm{M}$ phosphate at a dilution of $0.3 \mathrm{~d}^{-1}$ ), and after $20 \mathrm{~d}$ of growth with 0 dilution, after which the cultures were diluted over $24 \mathrm{~h}$ to $20 \%$ of their original volume with fresh medium and allowed to grow (under batch culture conditions) for a further $28 \mathrm{~d}$.

\section{RESULTS}

A survey of the qualitative composition of the dinoflagellates showed that, with the exception of Alexandrium tamarense, all contained significant amounts of the unidentified neutral charged nonprotein amine X (see Flynn \& Flynn 1992 for data of Aureodinium pigmentosum). All contained the nonprotein amino acid taurine. The larger cells contained more InAA but the typical concentration of glutamate was 10 to $20 \mathrm{mM}$ for all the dinoflagellates tested. Data for glutamate, glutamine, arginine, taurine and amine $\mathrm{X}$ are presented. Aspartate, serine and glycine were present at around 5 to $10 \mathrm{mM}$ and concentrations for the other amino acids were usually lower than $1 \mathrm{mM}$. For a large species such as Gymnodinium. catenatum, an extract from 200 to 500 cells was sufficient for InAA analysis. For smaller species larger numbers are required (e.g. 1000 to 2000 cells of Heterocapsa triquetra).

Examinations of changes of the InAA content over a L/D cycle (Fig. 1) suggest that there were cyclic changes, not only associated with changes in irradiance per se but also with cell cycle events; some of the changes occurred during the latter part of the light phase. The typical pattern is seen in Glenodinium foliaceum and Proracentrum micans (Fig. 1a, b). Changes in amine $X$ generally followed those of glutamate, although the proportion of $\mathrm{X}$ could vary considerably between species (compare Heterocapsa triquetra in Figs. $1 c \& 3 d$ with the others) and declined during $N$ - 

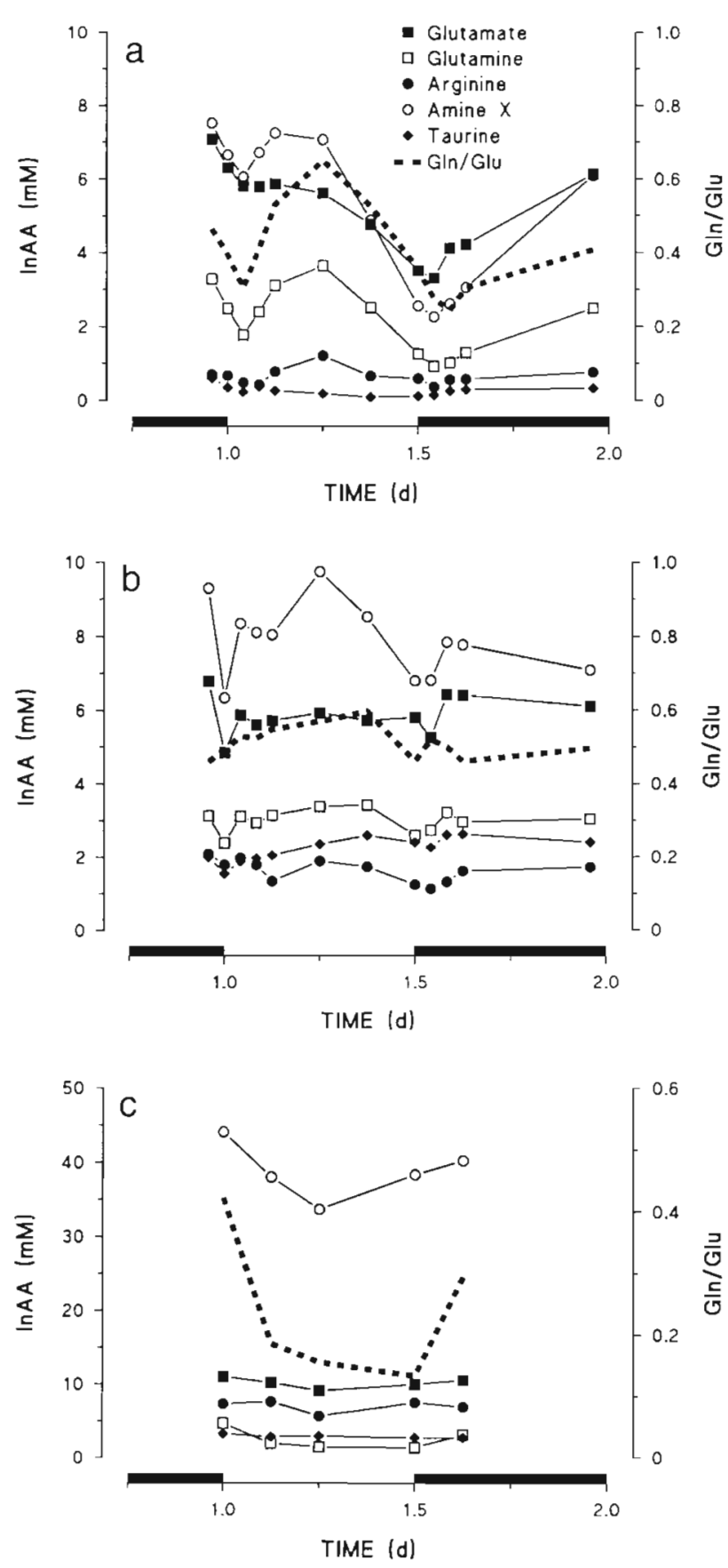

Fig. 1 Patterns of changes in intracellular free amino acids (InAA) and the ratio of intracellular free glutamine/glutamate (Gin/Glu) during growth in a $12 \mathrm{~h} / 12 \mathrm{~h}$ light/dark cycle of

(a) Glenodinium foliaceum, (b) prorocentrum micans and (c) Heterocapsa triquetra

deprivation (e.g. Fig. 3a, b). There were changes in Gln/Glu during the diurnal cycle, but the ratio did not fall significantly if at all during the dark phase (Fig. 1).

Studies using N-limited continuous cultures of Prorocentrum micans and Scrippsiella trochoidea (Fig. 2)
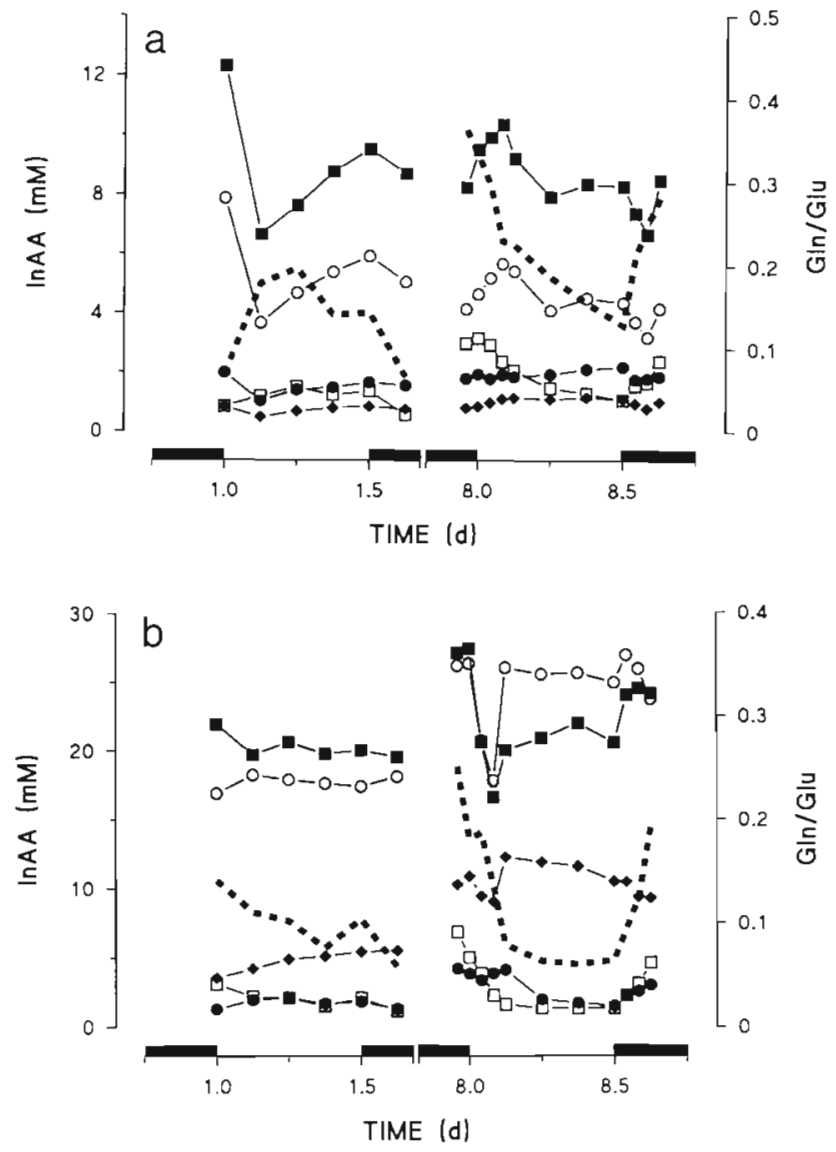

Fig. 2. Effects of growing (a) Prorocentrum micans and (b) Scrippsiella trochoidea in N-limited culture either fed with nitrate during the entire light/dark phase (first time period) or just during the dark phase (second time period). Symbols as in Fig. 1

showed how InAA altered with either the continuous addition of medium (L \& D feeding) or by addition during the dark phase only ( $D$ feeding). During $L \& D$ feeding the N-status, as indicated by Gln/Glu, remained low throughout the cycle, while during $D$ feeding the ratio was highest during the dark phase, falling after the lights came on. Glutamate correlated with amine $\mathrm{X}$ for both species during both treatments.

Samples from cultures which had been grown until the nitrate had been exhausted and then subjected to ammonium spiking $(10 \mu \mathrm{M})$ showed a rapid increase in Gln/Glu and slower changes in other amino acids (Fig. 3). There was a difference between the spiking of $\mathrm{N}$-deprived (Fig. 3a) and N-starved stationary phase (Fig. 3b) Prorocentrum micans; in the latter, levels of most components of InAA were lower and Gln/Glu increased more rapidly and to a higher level. Gymnodinium catenatum showed a slow response most likely because the general physiology of the culture had 

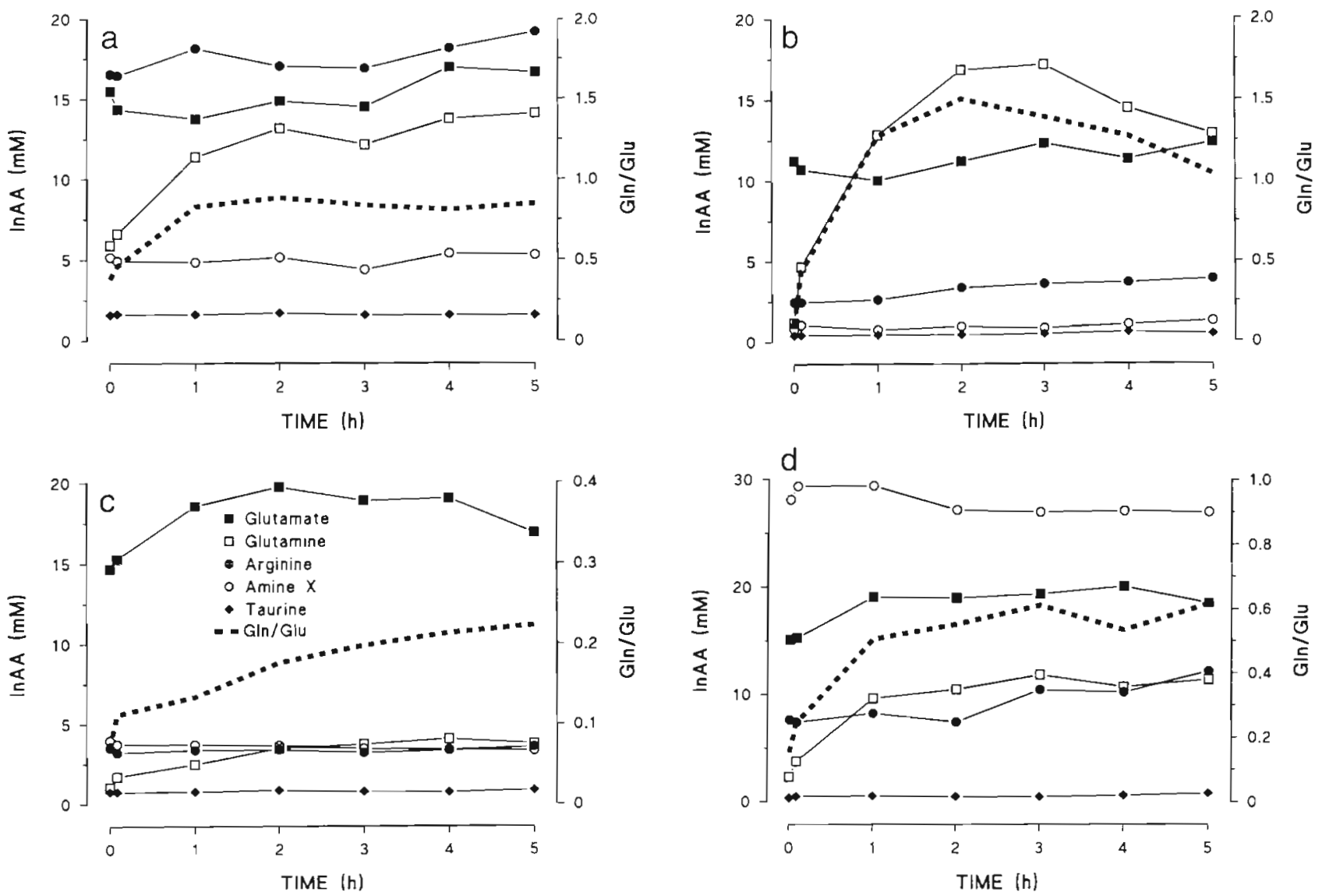

Fig. 3. Effect of ammonium-spiking $\left(10 \mu \mathrm{M} \mathrm{NH}_{4}{ }^{+}\right)$of cultures of (a) recently $\mathrm{N}$-deprived and (b) N-starved Prorocentrum micans, (c) Gymnodinium catenatum and (d) Heterocapsa triquetra which had exhausted the nitrate from the growth medium
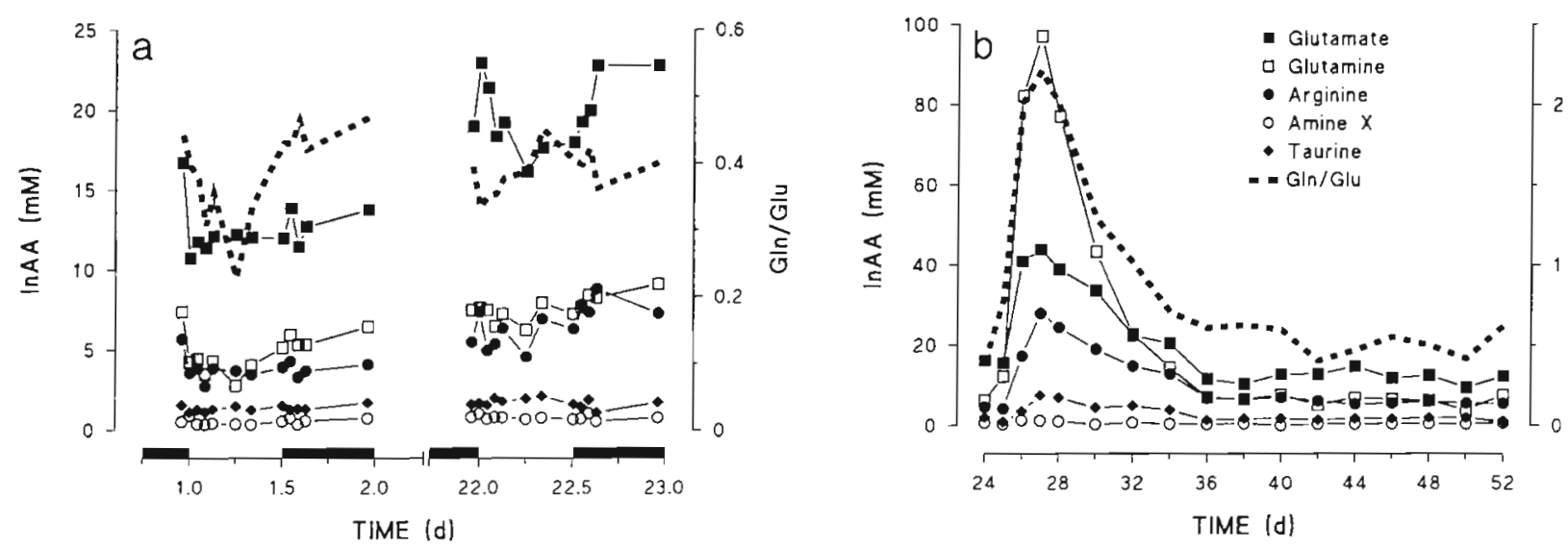

Fig. 4. Changes in intracellular free amino acids (InAA) and the ratio of intracellular free glutamine/glutamate (Gin/Glu) for Alexandrium tamarense (a) during $\mathrm{N}$-limited growth at a dilution rate of $0.3 \mathrm{~d}^{-1}$ (first time period) and after $20 \mathrm{~d}$ of $\mathrm{N}$-starvation (second time period), and (b) then for batch growth following a dilution with fresh medium. 

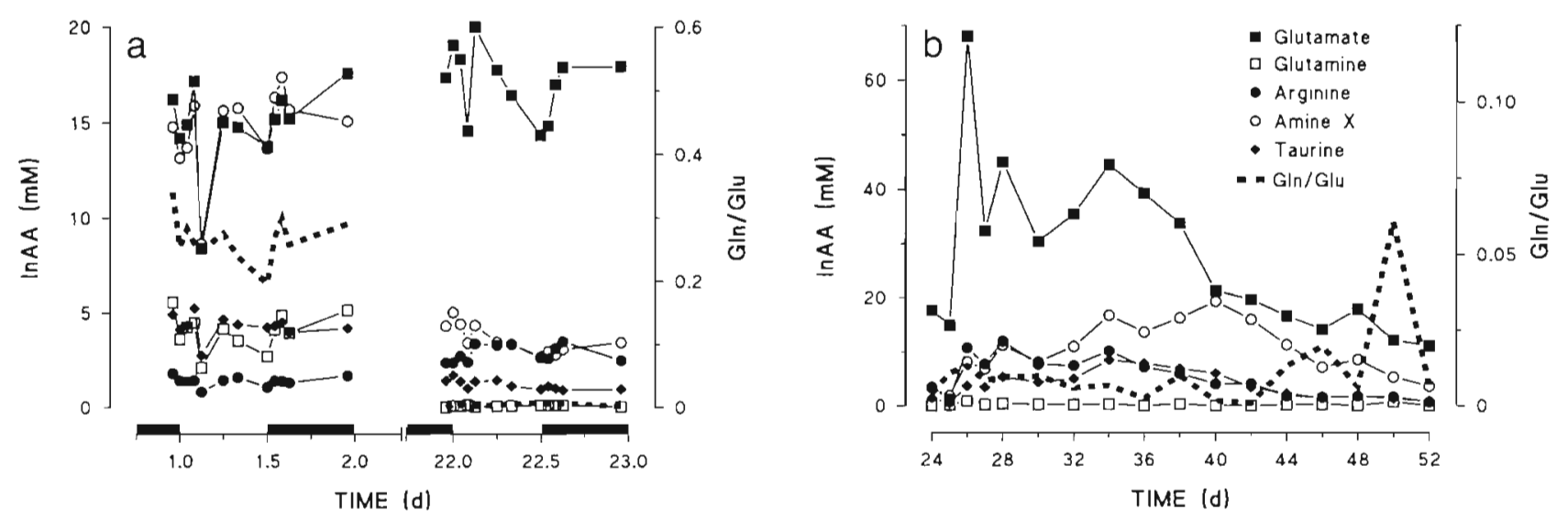

Fig. 5. As in Fig. 4 but for Gymnodinium catenatum

changed significantly in stationary phase (cells appeared abnormal and moved slowly if at all).

Comparison of the growth of Alexandrium tamarense and Gymnodinium catenatum during N-limited growth (dilution rate of $0.3 \mathrm{~d}^{-1}$ ), after $20 \mathrm{~d}$ of $\mathrm{N}$-starvation and then following an $80 \%$ dilution with fresh medium containing $20 \mu \mathrm{M}$ nitrate and $5 \mu \mathrm{M}$ phosphate, illustrates the contrasts between these algae (Figs. 4 \& 5). A. tamarense did not have significant amounts of the amine $X$ at any time (Fig. 4) and retained high residual levels of glutamine and Gln/Glu (never falling below 0.4 ). The response to nitrate refeeding of $A$. tamarense was rapid with an increase in InAA and of Gln/Glu (Fig. 4b). Cell numbers increased from 300 to $1750 \mathrm{ml}^{-1}$ between Days 24 and 40, and then remained constant.

In contrast, Gymnodinium catenatum had a higher Gln/Glu during the original continuous culture phase (during which amine X correlated with glutamate) than when $\mathrm{N}$-starved (Fig. 5a). On dilution of the starved culture with fresh medium the recovery was slow with increasing levels most apparent for glutamate, $\mathrm{X}$ and arginine (which on an $\mathrm{N}$ basis was similar to that of glutamate; Fig. 5b). Cell numbers increased from 100 to $300 \mathrm{ml}^{-1}$ by Day 46; the concentration of amine $\mathrm{X}$ had declined by this time.

For both Alexandrium tamarense and Gymnodinium catenatum concentrations of taurine were higher ( $8 \mathrm{mM}$ ) during $\mathrm{N}$-sufficient growth, falling to $2 \mathrm{mM}$ by Days 36 (Fig. 4b) and 46 (Fig. 5b) respectively. A similar pattern was seen in the other species (e.g. Fig. $3 a, b$ for Prorocentrum micans).

Concentrations of DFAA were generally low with the typical major constituents being glutamate, serine, glycine and alanine at around 20 to $40 \mathrm{nM}$ each. However, with DFAA from Gymnodinium catenatum, a significant quantity of an unidentified o-phthal- dialdehyde-positive extracellular product was noted (Fig. 6).

\section{DISCUSSION}

Three general points are of note from the initial examinations of the qualitative composition of InAA in dinoflagellates.

Firstly, the sensitivity of the analysis system is adequate for sampling dinoflagellates at natural cell den-

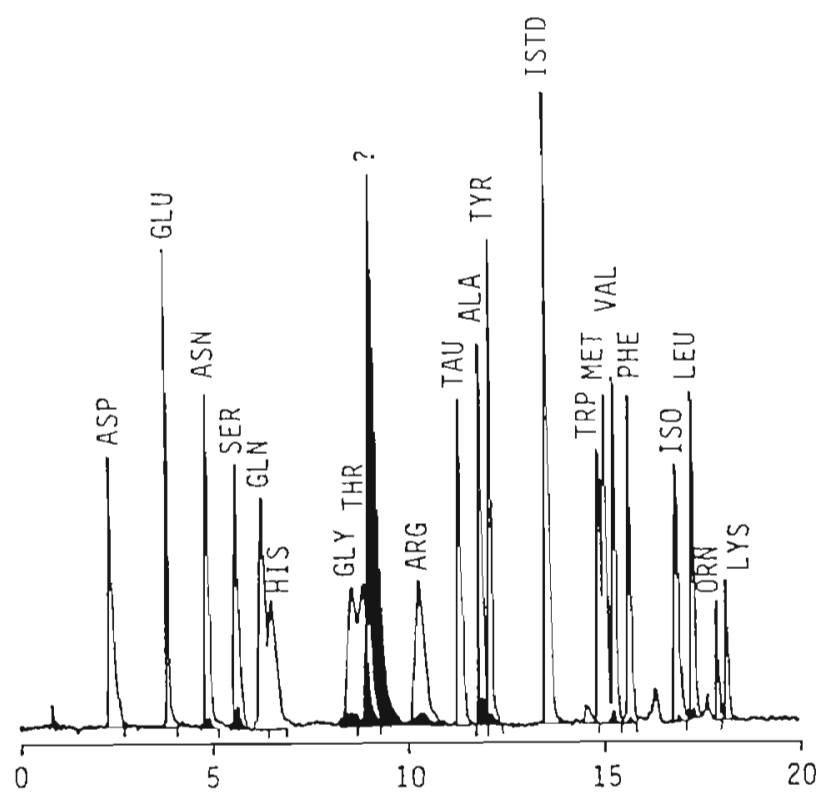

Fig. 6. Chromatogram of an amino acid standard (each peak of $200 \mathrm{nM}$ ) overlaid on one of dissolved free amino acids (DFAA) from the culture medium of Gymnodinium catenatum (closed peaks). Note the large unidentified peak after threonine 
sities, requiring the collection of only 200 to 2000 cells. We have subsequently used our methods with natural mixed populations of dinoflagellates (K. J. Flynn, K. J. Jones, R. Raine, J. Richards \& K. Flynn unpubl.) where, with chlorophyll concentrations of around $1 \mathrm{Mg} \mathrm{l}^{-1}$, the equivalent of only $20 \mathrm{ml}$ of suspension was required for analysis. Also, during the dark phase of growth, glutamine and the Gln/Glu ratio did not fall as noted in some other algae (e.g. Isochrysis galbana and Dunaliella primolecta; Flynn 1990a). Rather the ratio remained at a similar level or increased. This is convenient because it means that Gln/Glu can be used without undue complications during field studies of dinoflagellate populations. There was, however, evidence of either circadian rhythms or changes in InAA with cell cycle events during growth in a $12 \mathrm{~h} / 12 \mathrm{~h} \mathrm{L/D}$ cycle (Fig 1 ).

Secondly, amino acids such as arginine, with a high N/C ratio, are often present at high concentration and in some instances represent the largest single component of identified InAA on an amino- $N$ basis. This may be so even in $\mathrm{N}$-starved cells, whereas in other algae arginine is only a minor (barely detectable) component of InAA under such circumstances (Flynn 1990b). The implication is that any of these organisms has the potential for supplying arginine, an important component for PSP toxin synthesis (Shimizu et al. 1990) be that synthesis by the dinoflagellate or by associated bacteria (Rausch de Traubenberg \& Lassus 1991).

Thirdly, there is clearly a fundamental difference in the $\mathrm{N}$-biochemistry of Alexandrium spp. in comparison with the others. Both a nontoxic $A$. tamarense and a toxic $A$. minutum (not shown) were unique amongst those dinoflagellates tested in having insignificant amounts of the nonprotein amine $X$. All other autotrophic dinoflagellates (but not the heterotrophic Oxyrrhis marina), plus the diatoms and prymnesiophytes that we have tested, do have X (Flynn \& Flynn 1992). In most dinoflagellates, the concentration of $X$ correlated with that of glutamate (e.g. Fig. 2), although the level relative to glutamate fell during $\mathrm{N}$-deprivation (e.g. Fig. 3a, b) when glutamine was also low. Alexandrium spp. also exhibit a relatively high Gln/Glu at all times; this is due to high glutamine not a low glutamate relative to other amines. We have tested extracts of both species of Alexandrium with 2 different HPLC solvent systems (as detailed in Flynn \& Flynn 1992) and find no evidence for a coeluting compound with glutamine. The question of the interactions between glutamine, glutamate and amine $\mathrm{X}$ will have to await the positive identification of $X$, but the absence of significant $X$ and of permanently elevated levels of glutamine in Alexandrium spp. may be linked.

The other nonprotein amine present, taurine, occurred at lower concentrations in stationary phase cells. In the heterotrophic dinoflagellate Oxyrrhis marina taurine concentrations are lowest when the cells are packed with prey (K. J. Flynn, K. Davidson \& A. Cunningham unpubl.). It would appear that taurine is a component of the cytoplasm and that processes of vacuolation (in old autotrophic or prey-replete phagotrophic cells) lead to a decrease in concentration on a cell volume basis.

Comparisons of the InAA results with those obtained by others are difficult. Turpin \& Harrison (1978), examining Gymnodinium simplex, employed a dedicated amino acid analyzer (which may well have not detected nonprotein amino acids) and these authors give little information for amino acids other than glutamate and glutamine. Martin-Jézéquel et al. (1988) used $o$-phthaldialdehyde derivatization of amino acids (as used here) but we suspect (Flynn \& Flynn 1992) that amine $\mathrm{X}$ either coeluted with glutamine or that it was misidentified as histidine in their HPLC.

A point of note for attempts to study the $\mathrm{N}$-physiology of dinoflagellates is that often, unless the $\mathrm{N}$-source concentrations are initially low (around 20 and not above $50 \mu \mathrm{M}$ ), significant $N$-stress (gauged by Gln/Glu and the relative proportions of $\mathrm{N}$-rich amino acids in InAA) may not occur because growth is terminated by some other event (Dixon \& Syrett 1988). Consistent with this is the often high, and sometimes extremely high, concentrations of $\mathrm{N}$-rich amino acids such as arginine which accumulate in cultures grown on unmodified $\mathrm{f} / 2$ medium (which contains a large excess of $880 \mu \mathrm{MN}$ to $36 \mu \mathrm{M} \mathrm{P}$ ). An example of this is seen in the data of Martin-Jézéquel et al. (1988) for stationary phase dinoflagellates; these cells still contained high percentages of glutamine.

Refeeding of $\mathrm{N}$-limited cells with nitrate during the dark phase only of growth in a L/D cycle resulted in an elevated Gln/Glu ratio which declined during early light phase (Fig. 2). These experiments attempted to mimic the encounter of nutrients following vertical migration to the nutricline during the hours of darkness. Although the experiments were conducted in 21 flasks there was still an accumulation of cells at the bottom towards the end of the light phase, and near

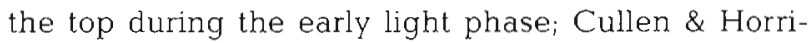
gan (1981) report similar behaviour. Some degree (extent unknown) of nitrate assimilation clearly proceeds during darkness (Paasche et al. 1984) else glutamine would not accumulate. The extent to which nitrate-N is retained as nitrate or passes through to organics is not known but there is no significant accumulation of In $A$ A so protein synthesis would not appear to be the rate limiting step.

An additional way to use InAA and Gin/Glu in order to study the N-physiology of a population is to test the response with an addition of ammonium. 
Cells which are $\mathrm{N}$-replete will show little response while having a relatively high initial Gln/Glu ratio. Cells which are $\mathrm{N}$-deprived but otherwise undamaged show a rapid change in Gin/Glu from a low initial value, while a small response with a low initial value indicates that only a small proportion of the population is active and/or N-starved (Flynn et al. 1989). The response of dinoflagellates to the addition of ammonium (Fig. 3) is similar to that seen with other algae (Flynn 1990a). As noted before, but yet to be tested rigourously, the peak value of Gln/Glu following an ammonium spike increases with increasing $\mathrm{N}$-stress (shown here with Prorocentrum micans; Fig. 3a, b).

The response of stationary phase Gymnodinium catenatum to an increased availability of nitrate (Fig. 5b) is curious. The cells of this culture had an abnormal appearance and poor motility. While they responded to the input of fresh nutrients, in that the cells divided, the response seen in other algae of a rapid recovery in levels of glutamine and of a rise in the ratio of Gin/Glu was absent. Glutamate, rather than glutamine, responded. This may have resulted from $\mathrm{N}$-assimilation through glutamate dehydrogenase (GDH, synthesizing Glu from ketoglutarate + intracellular $\mathrm{NH}_{4}^{+}$) rather than through glutamine synthetase (GS, giving Gln from Glu $+\mathrm{NH}_{4}{ }^{+}$). We have noted subsequently a similar response in a natural population of dinoflagellates which had aggregated due to advective processes (K. J. Flynn, K. J. Jones, R. Raine, J. Richards \& K. Flynn unpubl.).

From this work it would appear that InAA analysis could give an indication of the general physiological status, as well as the $\mathrm{N}$-status, of natural populations such as the accumulation of Gyrodinium cf. aureolum reported by Jiménez et al. (1992). It would also be interesting to test the effects of high photon flux densities, shown to inhibit photosynthesis (Garcia \& Purdie 1992), on CN physiology. If the CN physiology of 'red tide' accumulations is different to that of other populations then this would have implications for the ecology of these populations and their responses to perturbations such as encountering anthropogenic inputs of nutrients in coastal waters.

Finally, the composition of DFAA was similar to that for other algae (Flynn 1990b), with aspartate, glutamate, serine, glycine and alanine as important components. There were also some unidentified peaks but only for Gymnodinium catenatum was one of these of significance (Fig. 6). What this compound was is not known but it was not present in extracts from the cells at any noticeable concentration. The compound may have not be a product of the dinoflagellate per se, but of the associated bacterial community. Trick et al. (1981) also report the presence of an extracellular sec- ondary metabolite but that from Prorocentrum minimum was not nitrogenous.

Acknowledgements. This work was funded by the Natural Environment Research Council. The authors thank Dr S. Fraga ([EO, Vigo) for the culture of Gymnodinium catenatum.

\section{LITERATURE CITED}

Anderson, D. M., Kulis, D. M., Sullivan, J. J., Lee, C. (1990). Dynamics and physiology of saxitoxin production by the dinoflagellates Alexandrium spp. Mar. Biol. 104: 511-524

Cullen, J. J., Horrigan, S. G. (1981). Effects of nitrate on the diurnal vertical migration, carbon to nitrogen ratio, and the photosynthetic capacity of the dinoflagellate Gymnodinium splendens. Mar. Biol. 62: 81-89

Dixon, G. K., Syrett, P. J. (1988). The growth of dinoflagellates in laboratory cultures. New Phytol. 109: 297-302

Figueiras, F. G., Fraga, F. (1990). Vertical nutrient transport during proliferation of Gymnodinium catenatum Graham in Ria de Vigo, northwest Spain. In: Granéli, E., Sundström, B., Edler, L., Anderson, D. M. (eds.) Toxic marine phytoplankton. Elsevier, New York, p. 144-148

Figueiras, F. G., Pazos, Y (1991). Hydrography and phytoplankton of the Ría de Vigo before and during a red tide of Gymnodinium catenatum Graham. J. Plankton Res. 13: $589-608$

Flynn, K. J. (1988). Some practical aspects of measurement of dissolved free amino acids in natural waters and within microalgae by the use of HPLC. Chem. Ecol. 3: 269-293

Flynn, K. J (1990a). The determination of nitrogen status in microalgae. Mar. Ecol. Prog. Ser. 61: 297-307

Flynn, K. J. (1990b). Composition of intracellular and extracellular pools of amino acids, and amino acid utilization of microalgae of different sizes. J. exp. mar. Biol. Ecol. 139: $151-166$

Flynn, K. J., Dickson, D. M. J., Al-Amoudi, O. A. (1989). The ratio of glutamine: glutamate in microalgae: a biomarker for $\mathrm{N}$-status suitable for use at natural cell densities. J. Plankton Res. 11: 165-170

Flynn, K. J., Flynn, K. (1992). Nonprotein amino acids in microalgae: consequences for the estimation of the glutamine/glutamate ratio. Mar. Ecol. Prog. Ser. 89: 73-79

Franks, P. J. S., Anderson, D. M. (1992). Alongshore transport of a toxic phytoplankton bloom in a buoyancy current: Alexandrium tamarense in the Gulf of Maine. Mar. Biol. 112: $153-164$

Garcia, V. M. T., Purdie, D. A. (1992). The influence of irradiance on growth, photosynthesis and respiration of Gyrodinium cf. aureolum. J. Plankton Res. 14: 1251-1265

Guillard, R. R. L., Ryther, J. H. (1962). Studies of marine planktonic diatoms. I. Cyclotella nana Hustedt and Detonula confervacea (Cleve) Gran. Can. J. Microbiol. 8: 229-239

Holligan, P. M., Williams, P. J. LeB., Purdie, D. A., Harris, R. P. (1984). Photosynthesis, respiration and nitrogen supply of planktonic populations in stratified, frontal and tidally mixed shelf waters. Mar. Ecol. Prog. Ser. 17: 201-213

Jiménez, C., Niell, F. X., Figueiras, F. G., Clavero, V., Algarra, P., Buela, B. (1992). Green mass aggregations of Gyrodinium cf. aureolum Hulbert in the Ria of Pontevedra (northwest Spain). J. Plankton Res. 14: 705-720

Le Févre, J. (1986). Aspects of the biology of frontal systems. Adv. mar. Biol. 23: 163-299

Martin-Jézéquel, V., Poulet, S. A., Harris, R. P., Moal, J., Samain, J. F. (1988). Interspecific and intraspecific compo- 
sition and variation of free amino acids in marine phytoplankton. Mar. Ecol. Prog. Ser. 44: 303-313

Paasche, E., Bryceson, I., Tangen, K. (1984). Interspecific variation in dark nitrogen uptake by dinoflagellates. J. Phycol. 20: $394-401$

Rausch de Traubenberg, C., Lassus, P. (1991). Dinoflagellate toxicity: are marine bacteria involved? Mar. microb. Fd Webs 5: 205-226

Shimizu, Y., Gupta, S., Pradad, A. V. K. (1990). Biosynthesis of dinoflagellate toxins. In: Granéli, E., Sundström, B., Edler,

This article was presented by J. W. Leftley, Oban, Scotland, UK
L., Anderson, D. M. (eds.) Toxic marine phytoplankton. Elsevier, New York, p. 62-71

Trick, C. G., Harrison, P. J., Andersen, R. J. (1981). Extracellular secondary metabolite production by the marine dinoflagellate Prorocentrum minimum in culture. Can. J. Fish. Aquat. Sci. 38: 864-867

Turpin, D. H., Harrison, P. J. (1978). Fluctuations in free amino acid pools of Gymnodinium simplex (Dinophyceae) in response to ammonia perturbation: evidence for glutamine synthetase pathway. J. Phycol. 14: 461-464

Manuscript first received: February 1, 1993

Revised version accepted: June 29, 1993 